\title{
PLAGIARISME DALAM PENULISAN KARYA ILMIAH MAHASISWA: PROSES, BENTUK, DAN FAKTOR PENYEBAB
}

\author{
Oleh: \\ Ruslan, Hendra, Nurfitriati \\ Institut Agama Islam Muhammadiyah Bima \\ ruslanamarizqi@gmail.com
}

\begin{abstract}
Abstrak:
Tujuan penelitian ini adalah mengungkap proses, bentuk dan factor penyebab plagiarism dalam penulisan karya ilmiah mahasiswa beberapa perguruan tinggi di Bima. Penelitian ini merupakan penelitian kualitatif deskriptif yang dilakukan dengan tiga tehnik pengumpulan data, yaitu tehnik observasi, wawancara, dan dokumentasi. Analisis data mengikuti tiga alur dari Miles dan Huberman yang mencakup reduksi data, penyajian data, dan penyimpulan. Hasil penelitian ini menunjukan bahwa plagiarisme yang dilakukan oleh mahasiswa pada beberapa perguruan tinggi di Bima, dengan cara: Pertama, menitipkan judul tugas pada agen yang terpercaya dalam membuat sebuah karya ilmiah, dengan batasan waktu maksimal satu minggu, maka karya ilmiah yang dipesan dapat diambil oleh mahasiswa (gosh writer). Kedua, bentuk plagiarisme yang dominan dilakukan oleh mahasiswa adalah plagiat serentak yaitu melakukan gunting tempel karya ilmiah milik orang lain seutuhnya dan dijadikan seolah karya ilmiah milik sendiri atau juga disebut dengan complete plagiarism. Selain bentuk tersebut, beberapa mahasiswa mengambil teks dari suatu sumber, kemudian dilakukan parafrase namun tidak disebut sumbernya, seakan teks tesebut asli miliknya atau disebut juga dengan paraphrasing plagiat. Ketiga, faktor penyebab plagiarisme dalam penulisan karya ilmiah mahasiswa beberapa perguruan tinggi di Bima adalah karena pemahaman yang kurang baik tentang kategori plagiat, tidak memahami tata cara penulisan termasuk pengutipan yang benar sesuai dengan pedoman penulisan karya ilmiah masing-masing perguruan tinggi, rasa malas, dan perasaan yang menganggap tugas berupa karya ilmiah yang diberikan ialah sebuah beban.
\end{abstract}

Kata Kunci: Plagiarisme, Karya Ilmiah, Mahasiswa.

\section{Pendahuluan}

Salah satu sarana penting guna membangun sumber daya manusia berkualitas sekaligus yang bermoral ialah jalur pendidikan (human investment), yang secara formal bermula dari tingkat pendidikan dasar 
hingga perguruan tinggi. Melalui proses pendidikan generasi diharapkan semakin baik dan semakin maju dibanding dengan generasi-generasi sebelumnya. Oleh karenanya pengaruh perguruan tinggi dalam proses peningkatan sumber daya manusia amat sentral, dan relatif banyak informasi yang banyak dibaca. ${ }^{1}$

Pendidikan juga menjadi karakteristik penting maju atau tidaknya sebuah peradaban, dan pendidikan ditandai terutama oleh kemampuan manulis. Menulis merupakan manisfestasi dari apa yang dipikirkan oleh seseorang, dan semua itu akan mejadi warisan penting yang dapat dinikmati oleh generasi-generasi berikutnya sebagai mata rantai perkembangan ilmu dan peradaban. Karena itu menulis, meneliti dan membaca merupakan satu kesatuan yang tidak bisa tepisahkan. ${ }^{2}$ Dalam dunia akademik, karya ilmiah menempati posisi sentral. Penghargaan tinggipun diberikan kepada mereka yang mempunyai kemampuan menulis karya ilmiah, lebih-lebih pada mereka yang produktif. ${ }^{3}$ Karena itu membangun tradisi kemampuan menulis merupakan sesuatu yang tidak terelakkan. Pada waktu yang sama penulisan karya ilmiah tidak mungkin berhasil dengan baik tanpa didukung dengan tradisi membaca karya ilmiah dengan baik. Tradisi menulis dan membaca dengan baik merupakan hal pertama bagi acitivitas akademis perguruan tinggi, karena setiap penulis yang baik terdapat pembaca yang baik.

Dalam penulisan karya ilmiah selain mengedepankan pengetahuan dan produktifitas juga harus mengedepankan etika dalam sebuah penulisan karya ilmiah, karena bagaimanapun karya ilmiah digunakan sebagi bahan penyelesaian tugas dalam jalur pendidikan khususnya pendidikan tinggi. Oleh sebab itu perlu diketahui bahwa pendidikan itu tidak hanya ditunjukan pada pengembangan intelektual manusia tetapi pendidikan pula ditunjukan untuk mengembangkan manusia agar menjadi insan yang seutuhnya. Oleh sebab itu dibutuhkan pembinaan sikap, moral, dan pembentukan karakter manusia sehingga antara rasio dan nurani dapat saling mengendalikan dan melengkapi. ${ }^{4}$

Seiring dengan perkembangan IPTEK (Ilmu Pengetahuan dan Teknologi) banyak memberikan dampak pada pelaku pendidikan

\footnotetext{
Press, 2013),

${ }^{2}$ Ibid., 130.

Ibid., 130 .

. Cblidi,ruBAnwar, Hakikat Manusia Dalam Pendidikan, (Yogyakarta, Suka-

${ }^{4}$ Chairul Anwar, Hakikat Manusia Dalam Pendidikan, (Yogyakarta, SukaPress, 2014),
}

${ }^{1}$ Akh. Minhaji, Tradisi Akademik Di Perguruan Tinggi, (Yogyakarta:Suka- 
tersebut khususnya pada Perguruan Tinggi (PT). Misalnya mahasiswa lebih condong menjadikan internet sebagai alat untuk menghasilkan sebuah karya ilmiah, dari pada melakukan kutipan langsung dari buku. Internet memang lebih banyak memberikan kemudahan sudah tidak dipungkiri lagi betapa cerdasnya 'om google' sebagai situs pencari di dunia maya. Hanya dengan menuliskan kata perintah apa saja sesuai dengan keinginan dan kebutuhan maka google akan menampilkannya termasuk salah satunya ialah karya ilmiah baik yang berupa makalah, skripsi, tesis, disertasi dan lain lain.

Namun hal ini juga melahirkan rasa tidak tanggungjawab oleh sebagian pengguna karena dengan mudahnya karya ilmiah di copy paste dan dijadikan sebagai karya sendiri tanpa sedikitpun mencantumkan nama pemilik karya tersebut. Kegiatan ini lebih dikenal dengan tindak "Plagiat". Hal ini menjadi ancaman etika dalam tradisi akademik, khususnya pada kegiatan tulis menulis.

Kritikan bahkan hujatan terhadap praktek plagiat sudah sering dilontarkan, tapi nampaknya hal ini belum mampu mencegah praktek kotor tersebut. Hal ini bukan hanya terjadi pada tinggkat pendidikan S1 (Strata 1) tetapi juga pada tingkat pendidikan S2 (Strata 2) maupun S3 (Strata 3). Bahkan disinyalir merambah ke guru besar umumnya bahwa saat ini tidak sulit mendapatkan layanan-layanan penulisan karya ilmiah yang tidak sekedar membantu tetapi juga menuliskan secara utuh. $^{5}$

Mahfud MD dalam Minhaji mensinyalir bahwa praktek plagiat merambah ke hampir semua lini masyarakat. Dan tidak jarang seorang dosen menggunakan karya mahasiswa bimbingannya yang diklaim sebagai karya sendiri. Ia menegaskan bahwa saat ini banyak karya tulis hasil plagiat atau gost writer (penulis berhantu) yang dibayar oleh penulis formalnya. ${ }^{6}$ Sejumlah aturan tentang plagiat memang sudah ada, seperti dalam Peraturan Menteri Pendidikan Nasional Republik Indonesia Nomor 17 Tahun 2010 Tentang Pencegahan dan Penanggulangan Plagiat di Perguruan Tinggi. Dalam aturan tersebut dikemukakan: 1) Bahwa setiap perguruan tinggi mengemban misi untuk mencari, menemukan, mempertahankan, dan menjunjung tinggi kebenaran; 2) Bahwa untuk memenuhi misi tersebut, mahasiswa/dosen/peneliti/tenaga kependidikan yang berkarya di bidang akademik di perguruan tinggi memiliki otonomi keilmuan dan

\footnotetext{
${ }^{5}$ Minhaji, Tradisi Akademik.........., 150.

${ }^{6}$ Ibid., 151.
} 
kebebasan akademik; dan 3) Bahwa dalam melaksanakan otonomi keilmuan dan kebebasan akademik, mahasiswa/dosen/peneliti/tenaga kependidikan wajib menjunjung tinggi kejujuran dan etika akademik, terutama larangan untuk melakukan plagiat dalam menghasilkan karya ilmiah, sehingga kreativitas dalam bidang akademik dapat tumbuh dan berkembang. $^{7}$

Bagi insan perguruan tinggi yang melakukan plagiarism, diancam dengan hukuman yang berat sesuai dengan UU No.20/2003. Dalam UU tersebut dijelaskan bahwa pelaku tindak plagiat diberikan sanksi bahwa lulusan perguruan tinggi yang karya ilmiahnya digunakan untuk memperoleh gelar akademik, profesi atau vokasi, terbukti merupakan jiplakan, dicabut gelarnya (pasal 25 ayat 2). Kemudian lulusan yang tersebut pada pasal 25 ayat 2 dipidana dengan pidana penjara paling lama dua tahun, dan atau pidana denda paling banyak Rp. 200.000.000,- (dua ratus juta rupiah). ${ }^{8}$

Meskipun undang-undang yang mengatur plagiat sudah ada, namun pada kenyataannya tindakan seperti itu masih marak dan sering terjadi di kalangan perguruan tinggi. Secara tidak langsung, hal ini menunjukkan bahwa aturan atau undang-undang tentang plagiat tersebut belum mempunyai kekuatan hukum yang kokoh, dan perlu pemikiran kreatif lain sebagai solusi mencegah terjadinya plagiat.

Sebagaimana yang sering terjadi akhir-akhir ini, permasalahan tindakan plagiat telah menjadi fenomena yang hangat dibicarakan pada forum-forum akademik. Hal ini terbukti dari berbagai kasus plagiat yang mencuat di media-media cetak maupun media visual, antara lain: Rektor ITB pada hari jum'at tanggal 23 april 2010 secara resmi menyatakan bahwa disertasi dan gelar doktor Mochammad Zuliansyah tidak berlaku. ${ }^{9}$ Sementara itu tiga dosen pembimbingnya diberikan surat teguran akibat kelalaiannya. Kasus lain yaitu 3 (tiga) dosen dari Universitas Pendidikan Indonesia diduga melakukan tindak plagiat hasil karya yang diajukan ke Direktorat Pendidikan Tinggi Kementrian Pendidikan dan Kebudayaan. Dari ke tiganya salah satu dosen plagiat dari hasil karya Universitas Padjadjaran. Selama satu tahun dosen tidak

\footnotetext{
${ }^{7}$ Ibid., 152

${ }^{8}$ Penjelasan Umum Undang-undang Nomor 20/2003sanksi bagi pelaku plagiat, Lembaran Negara Republik Indonesia Tahun 2005 Nomor 112, Jakarta.

${ }^{9}$ Https://Edukasi.Kompas.Com/Read/2010/04/20/10015667/Orang.Pintar. Plagiat.Kompas, diakses Pada 3 Februari 2019.
} 
boleh mengajukan guru besar dan semua dosen tidak dapat naik golongan atau pangkat. ${ }^{10}$

Kasus plagiarism sebagaimana tersebut di atas, juga terjadi di kalangan mahasiswa perguruan tinggi di Bima. Pada observasi awal di beberapa agen pembuatan karya ilmiah, penulis menemukan sebagian mahasiswa sering melakukan tindakan plagiarisme karya ilmiah baik dalam bentuk makalah maupun skripsi. Ada beberapa mahasiswa yang dengan enteng melakukan tindakan plagiat dalam penulisan karya ilmiah mulai dari karya ilmiah yang berupa makalah hingga karya ilmiah yang berupa skripsi. Kebiasaan yang sudah dilakukan sejak awal semester menjadi berakar hingga tahun ke tahun.

Pada semester dua ada beberapa mahasiswa yang menyelesaikan tugas kuliah yang berupa makalah di sebuah agen dengan sistem kerja petinipan tugas. Tugas dititipkan selama beberapa hari paling cepat tiga hari dan normalnya penitipan dilakukan selama tujuh hari di agen pembuat karya ilmiah. Sedangkan beberapa mahasiswa semester delapan melakukan tindakan palagiarisme baik dengan cara copy paste secara langsung dari skripsi yang judulnya hampir sama dengan judul skripsi yang disusun maupun berupa gosh writer (penulis berhantu) dengan bayarannya yang disesuaikan dengan kesepakatan bersama. ${ }^{11}$

Selain agen di luar kampus penulis juga menemukan agen di dalam kampus. Agen dalam kampus adalah mahasiswa pembuat skripsi. Alasan awal pelaku menggunakan jasa agen karena kesibukan, ketidaktahuan cara menulis karya ilmiah, sampai pada karena rasa malas dan menginginkan nilai tinggi tanpa harus menguras waktu dan tenaga sendiri, sehingga agen gosh writer lahir dengan tawaran tulisan karya ilmiah yang seolah menjadi solusi terbaik untuk menyelesaikan masalah mahasiswa. Padahal jika difikir dengan logika dan akal sehat hal tersebut merupakan pembodohan dan kebohongan akademik yang dilakukan oleh diri sendiri. Serta penyimpangan etika dan moralitas mahasiswa dalam sebuah perguruan tinggi. ${ }^{12}$

\section{Metode Penelitian}

Jenis penelitian yang digunakan dalam hal ini ialah kualitatif. Objek penelitian ini ialah mahasiswa dari perguruan tinggi umum dan keagamaan yakni mahasiswa Institut Agama Islam (IAI)

\footnotetext{
Seputar Indonesia 2012, di akses pada 2 maret 2019.

${ }^{11}$ Hasil Observasi, 21 November 2018, Jam 14:00 Wita.

${ }^{12}$ Faizuddin Harliyasyah, Plagiat Dalam Karya Atau Publikasi Ilmiah Dan Langkah Strategis Pencegahannya, "Libria", Vol 9, No 1, 103.
} 
Muhammadiyah Bima, Sekolah Tinggi Keguruan dan Ilmu Pendidikan (STKIP) Bima, dan Sekolah Tinggi Keguruan dan Ilmu Pendidikan (STKIP) Tamansiswa Bima, dan jasa pembuatan karya ilmiah. Metode pengumpulan data dalam hal ini ialah menggunakan metode wawancara, dokumentasi, dan dokumentasi. Instrument yang digunakan dalam menjawab rumusan penelitian ini ialah lembar pedoman wawancara, observasi, dan dokumen. Tehnik analisis data yang digunakan ialah analisis deskriptif dengan prosedurnya ialah pengumpulan data, reduksi data, penyajian data, dan penarikan kesimpulan.

\section{Pembahasan}

\section{Plagiarisme: Proses, Bentuk, dan Penyebab}

Ritzer dan Goodman dalam Rachmatul Candra Ariani mengatakan bahwa secara sosiologis, plagiarisme sangat penting untuk dikaji karena plagiarisme berhubungan dengan masyarakat yang berada dalam lingkungan akademis dimana tindakan-tindakan mereka merupakan hasil dari interaksi-interaksi sosial dan proses sosial. Perspektif yang cocok untuk menjelaskan plagiarisme adalah perspektif perilaku sosial. Dimana sosiologi perilaku memusatkan perhatian pada hubungan antara pengaruh perilaku seorang aktor terhadap lingkungan dan dampak lingkungan terhadap perilaku aktor. Sehingga kunci utama dalam perspektif ini adalah aktor dan lingkungannya. ${ }^{13}$

Teori pertukaran sosial dari George Homans dalam Febrina Nafisa Prihantini dan Dian Indudewi adalah salah satu teori yang berlandaskan perspektif perilaku sosial. Teori pertukaran Homans bertumpu pada asumsi bahwa orang terlibat dalam perilaku untuk memperoleh ganjaran atau menghindari hukuman. Menurut Homans, teori ini "membayangkan perilaku sosial sebagai pertukaran aktivitas, nyata atau tak nyata, dan kurang lebih sebagai pertukaran hadiah atau biaya, sekurang-kurangnya antara dua orang."

Beberapa teori Homans tentang proposisi bisa menjadi rujukan dalam memahami tindakan plagiarism oleh mahasiswa di perguruan tinggi di Bima. Menurut Homans, proposisi dapat diklasifikasikan menjadi proposisi sukses, proposisi stimulus, proposisi nilai, proposisi deprivasi satiasi, dan proposisi persetujuan agresi. Proposisi sukses

${ }^{13}$ Rachmatul Candra Ariani, "Opini Mahasiswa Fakultas Ilmu Sosial Dan Ilmu Politik Universitas Airlangga Terhadap Plagiarisme", Jurnal Social Dan Politik, Vol 18, No 2, 2016, 145 
untuk semua tindakan yang dilakukan seseorang, semakin sering tindakan khusus seseorang diberi hadiah, semakin besar kemungkinan orang melakukan tindakan itu. Proposisi stimulus; bila dalam kejadian di masa lalu dorongan tertentu atau sekumpulan dorongan telah menyebabkan tindakan orang diberi hadiah, maka makin serupa dorongan kini dengan dorongan di masa lalu, makin besar kemungkinan orang melakukan tindakan serupa. Proposisi nilai, makin tinggi nilai hasil tindakan seseorang bagi dirinya, makin besar kemungkinan ia melakukan tindakan itu. Proposisi deprivasi satiasi, makin sering seseorang menerima hadiah khusus di masa lalu yang dekat, makin kurang bernilai baginya setiap unit hadiah berikutnya. Adapun proposisi persetujuan agresi, bila tindakan orang tak mendapatkan hadiah yang ia harapkan atau menerima hukuman yang tidak ia harapkan, ia akan marah (proposisi A), bila tindakan seseorang menerima hadiah yang ia harapkan, maka ia akan puas, makin besar kemungkinannya melaksanakan tindakan yang disetujui dan akibat tindakan seperti itu akan makin bernilai baginya (proposisi B); proposisi rasionalitas, dalam memilih di antara berbagai tindakan alternatif, seseorang akan memilih satu diantaranya, yang dia anggap saat itu memiliki value (v), sebagai hasil, dikalikan dengan probablitas (p), untuk mendapatkan hasil, yang lebih besar. ${ }^{14}$

Jika dilihat dari aspek bentuk, maka plagiarisme yang muncul dalam penulisan karya ilmiah memiliki tiga bentuk, yaitu plagiat secara langsung dengan cara penulis mengutip atau mengcopi sumber secara langsung kata demi kata tanpa menyebutkan siapa penulis atau pemilik sumber. Seorang plagiator secara sadar menyalin ulang sebuah gagasan secara utuh lalu mengakuinya sebagai gagasan pribadi. Plagiat karena kutipan tidak jelas atau salah. Tepat tidaknya sebuah pengutipan merupakan tindakan plagiat yang menitikberatkan pada ketepatan dalam menuliskan rujukan. Plagiat mozaik yaitu penulis secara benar mengutip tetapi mengganti sebagian kata atau beberapa kata dalam kalimat (rework a paragraph) dengan kata-katanya sendiri tanpa menyebutkan kredit penulis sumber sehingga jika dibaca dan dicermati gagasan yang

${ }^{14}$ Febrina Nafisa Prihantini Dan Dian Indudewi, "Kesadaran Dan Perilaku Plagiarism Dikalangan Mahasiswa," Jurnal Dinamika Social Budaya, No. 1, Volume $18,2016,69$. 
ditulis mirip dengan sumber aslinya namun kalimat tersebut dituliskan bukan dalam bentuk kutipan. ${ }^{15}$

Kemunculan tindakan plagiarism tidaklah tiba-tiba dan lahir dengan sendirinya, melainkan didorong oleh factor factor tertentu. Selain didorong oleh factor pribadi pelaku, tindakan semacam ini juga didorong oleh factor dari luar diri penulis. ${ }^{16}$ Harqutanto mengatakan bahwa penyebab terjadinya plagiat ialah karena beban yang diterima peserta didik yang amat berlebih dan tidak sesuai dengan waktu yang tersedia, sehingga terjadilah "gunting temple" apalagi bila penulis yang dalam hal ini peserta didik tidak mengetahui cara melakukan sitasi atau perujukan dengan benar. ${ }^{17}$ Marshall dan Garry dalam Siti Wachidah meyebutkan ada beberapa alasan terjadinya tindakan plagiarisme yaitu kurangnya pengetahuan tentang aturan mengutip dan referensi, ketidak mampuan untuk mengatasi beban kerja dan ketrampilan manajemen waktu yang buruk, tekanan untuk mendapatkan prestasi yang bagus, kurangnya motivasi untuk berprestasi, kemalasan dan faktor budaya. ${ }^{18}$ Sehingga dapat disimpulkan faktor yang mempengaruhi seseorang untuk melakukan tindakan plagiat, terdorong dari dua faktor yaitu faktor eksternal yaitu faktor yang berada dari luar diri sendri. Dan faktor internal yaitu faktor yang berasal dari keinginan atau dorongan dalam diri sendiri.

\section{Proses dan Bentuk Plagiarisme dalam Penulisan Karya Ilmiah Mahasiswa}

Plagiarisme menjadi menarik dibicarakan karena Perguruan Tinggi merupakan agen pendidikan moral, pendidikan karakter sebagai dasar pembentukan kepribadian yang cerdas, mandiri, dan bernurani. Sehingga sangat ironis jika karya ilmiah merupakan produk plagiarism baik oleh mahasiswa, dosen, dan tenaga kependidikan di lingkungan perguruan tinggi.

Berdasarkan wawancara dengan mahasiswa semester dua sampai delapan dan beberapa orang dari agen pembuat karya ilmiah, mengakui bahwa proses yang dilakukan dalam penyusunan karya ilmiah ialah

${ }^{15}$ Putra R Marseb, Kiat Menghindari Plagiarism, (Jakarta: Indeks, 2011), 1314.

${ }^{16}$ Ibid., 108 .

${ }^{17}$ Herqutanto, "Runtuhnya Tembok Kejujuran Akademik", eJKi, Vol 1, No 1, 1 April 2013, Diakses 27 Maret 2019, Jam 9:48.

${ }^{18}$ Siti Wachidah, " Plagiarisme Dalam Kata-Kata Mahasiswa: Analisis Teks Dengan Pendekatan Fungsional,”Jurnal Linguistik Indonesia, “ No. 2 ,Volume $18,2013$. 
melalui proses penitipan judul tugas yang diberikan oleh dosen pengampu matakuliah kepada oknum yang dipercayai dapat atau ahli dalam membuat sebuah karya ilmiah. Proses penyusunan karya ilmiah oleh agen tersebut dalam kurun waktu 1 minggu untuk karya ilmiah berupa makalah, dalam bentuk plagiat serentak dimana sebuah karya ilmiah diambil secara utuh berdasarkan hasil unduhan dari internet dengan menggantikan nama pemilik asli menjadi nama mahasiswa oleh penulis berhantu tersebut (gost writer). Ada juga mahasiswa yang mengakui karya ilmiah berupa makalah maupun skripsi dibuat sendiri, akan tetapi ketika mereka menemukan kesulitan di tengah jalan, maka alternatif yang ditempuh ialah dengan cara mencari file karya ilmiah yang hampir mirip dengan karya ilmiah miliknya, lalu ada beberapa pendapat yang diambil sebagian dan ditambah dengan pendapat sendiri tanpa mencantumkan nama pemilik karya ilmiah tersebut, sehingga seolah-olah karya ilmiah itu mutlak hasil karyanya sendiri.

Bukti lain yang menyatakan kebenaran mahasiswa melakukan tindakan plagiat pada karya ilmiah ialah peneliti melakukan wawancara kepada oknum pembuat karya ilmiah mulai dari karya ilmiah berupa makalah hingga karya ilmiah berupa skripsi, beliau mengakui bahwa memang banyak mahasiswa yang datang menitipkan tugasnya bahkan tak jarang beliau kewalahan dalam melayani konsumennya oleh karenanya dibuatlah waktu atau batas pengambilan tugas 1 buah karya ilmiah berupa makalah di ambil satu minggu setelah judul tugas dititipkan dengan biaya Rp. 15.000 sampai Rp. 20.000/makalah. Prilaku plagiarism di kalangan mahasiswa baik STKIP Kota Bima,STKIP Taman siswa Bima, maupun IAI Muhammadiyah Bima dapat dibuktikan ketika ujian skripsi. Kebanyakan mahasiswa tidak mampu mempresentasikan poin-poin penting dari skripsi yang diajukan, sehingga mengakui bahwa skripsi yang dipresentasikan dibuatkan oleh jasa pembuat karya ilmiah yang ada di sekitar tiga kampus tersebut. Menurut F, dosen pada Institut Agama Islam Muhammadiyah Bima sering ditemukan karya ilmiah yang mengganjal seperti dari segi penulisan bahkan mahasiswa yang membawakan karya ilmiah tersebut tidak paham dengan pembahasan yang ada pada tugas yang dipresentasikan. ${ }^{19}$

Selain itu, kejahatan akademik semacam ini tidak hanya terjadi sekarang, tetapi sudah menjadi sebuah tradisi di kalangan akademik

\footnotetext{
${ }^{19}$ Wawancara, 17 Juli 2019.
} 
seperti kejadian di tahun 2004 atau 2005 terdapat kejadian salah seorang dosen diketahui membuat skripsi mahasiswa meski hal ini telah mampu ditanggulangi dengan mengeluarkan peraturan yang berupa ancaman pemecatan bagi dosen yang masih melakukan aktifitas tersebut. Prilaku plagiarism di kalangan mahasiswa juga diakui oleh $\mathrm{S}$, salah seorang dosen STKIP Tamansiswa dan M, dosen STKIP Kota Bima. Bentuk plagiarism yang dilakukan, terutama dalam penulisan skripsi sangat beragam. Ada yang langsung menyalin total karya orang lain yang ditemukan melalui pencarian google, ada juga dengan cara mengutip tanpa menyebut referensi rujukan, dan lain-lain. Tindakan semacam ini relevan dengan salah satu pendapat yang dikutip oleh Harliansyah sebagai berikut. Pertama, Secondary source.

Plagiasi tipe ini dimungkinkan terjadi ketika peneliti memanfaatkan sumber-sumber sekunder (seperti literature review). Peneliti hanya mengutip sumber-sumber primer yang disebut dalam sumber sekunder yang dibacanya dan tidak memberikan informasi (mengutip) sumber sekunder yang dibacanya. Kedua, Paraphrasing plagiat jenis ini beupa mengambil teks dari suatu sumber, kemudian dilakukan parafrase namun tidak disebut sumbernya, seakan teks tesebut asli miliknya. Ketiga, Complete plagiarism. Palgiasi secara total yaitu plagiat yang diambil secara utuh tampa mengubah sedikitpun dari karya ilmiah sebelumnya. ${ }^{20}$ Plagiat mempunyai ruang lingkup yang luas, tidak sekedar paham dengan pengertian plagiat dan tipe-tipe plagiat, tetapi harus memahami pula tata cara penulisan, kususnya cara pengutipan agar terhindar dari plagiat.

Berdasarkan penelitian tersebut terdapat banyak proses dan bentuk cara mereka melakukan plagiat tetapi bentuk plagiat yang paling sering ialah pagiat serentak yaitu plagiat yang mengutip secara total semua hasil karya ilmiah orang lain dan dijadikan seoah karya sendiri hal ini dilakukan melalui proses gosh writer atau penulis berhantu dimana karya ilmiah tersebut ditulis orang lain dengan proses kesepakatan pembayaran yang telah di tetukan sehingga jadilah sebuah karya ilmiah. Secara normatif, plagiat merupakan bagian dari kecurangan akademis karena tindakan menjiplak karya seseorang tanpa mencantumkan sumber tulisan tersebut merupakan tindakan salah. Dasar hukum tentang plagiat di Indonesia baru dibuat pada tahun 2010 yaitu Peraturan Menteri

${ }^{20}$ Faizuddin Harliansyah, "Plagiarisme dalam Karya Atau Publikasi Ilmiah dan Langkah Strategis Pencegahannya”, Jurnal Libria, Vol. 9, No. 1, Juni 2017. 
Pendidikan Nasional Republik Indonesia No. 17 tahun 2010 tentang Pencegahan dan Penanggulangan Plagiat di Perguruan Tinggi.

\section{Faktor-faktor Penyebab Plagiarisme dalam Penulisan Karya Ilmiah Mahasiswa}

Berdasarkan jawaban-jawaban mahasiswa dapat diketahui bahwa sebagian besar mahasiswa tidak paham dengan tata cara mengutip sumber pertama dari sumber kedua. Etikanya adalah mencantumkan pengarang asli dan pengutip pertama yang kemudian dikutip lagi oleh orang lain yang hendak menggunakan tulisan atau karya tersebut. Pengarang asli dinamakan sumber primer, sedangkan pengutip pertama dan seterusnya apabila menggunakan pengarang asli dalam karyanya kemudian dipublikasikan disebut sumber sekunder. Dalam pembuatan karya ilmiah kususnya dianjurkan untuk menggunakan sumber primer dan membatasi penggunaan sumber sekunder untuk menjaga orosinalitas karya ilmiah tersebut.

Selanjutnya, peneliti dilapangan menggali temuan lebih jauh terkait tindak plagiat di kalangan mahasiswa. Peneliti menanyakan kepada mahasiswa yang menjadi subjek penelitian alasan- alasan yang menyebabkan mereka melakukan tindakan plagiat.dari 10 orang mahasiswa yang diwawancarai 4 diantaranya mengaku yang menyebabkan mereka melakukan plagiat dengan menggunakan jasa penitipan (gosh writer) ialah karena rasa malas dan ketidak tauan dalam menyusun sebuah karya ilmiah, selain itu mereka mengakui penyebab lain berupa tidak memiliki bahan untuk membuat karya ilmiah seperti laptop, referensi yang sulit didapatkan serta ketidak mampuannya dalam menggunakan laptop. Selain itu 3 orang mengaku di kejar dead line untuk mengumpulkan tugas sedangkan untuk semester awal banyak sekali tugas yang harus di kerjakan oleh karena menurut mereka menitipkan tugas pada agen-agen tertentu menjadi solusi terbaik. Sedangkan 3 orang mahasiswa mengaku kewalahan jika karya ilmiah harus dikerjakan sendiri karena mereka juga harus bekerja sepulang kuliah. 3 orang selanjutnya megganggap tugas yang diberikan sebagai beban. Hal ini serupa dengan pendapat Harqutanto mengatakan bahwa penyebab terjadinya plagiat ialah karena beban yang diterima peserta didik yang amat berlebih dan tidak sesuai dengan waktu yang tersedia, sehingga terjadilah "gunting temple" apalagi bila penulis yang dalam hal 
ini peserta didik tidak mengetahui cara melakukan sitasi atau perujukan dengan benar. ${ }^{21}$

Beberapa asalan tersebut menjadi dasar alasan untuk memahasiswa melakukan tindakan plagiat, selain itu berkembangnya informasi tentang adanya agen pengetikan membuat tindakan plagiat semakin berkembang dari tahun ke tahun terbukti dengan pernyataan beberapa mahsiswa yang mengakui mengetahui informasi tentang adanya jasa pengetikan salah satunya saudari ayu w, yang mengatakan bahwa awalnya ia tidak tau ada jasa pembuat karya ilmiah tetapi begitu mendengar dari kakak kos tempat ia tingggal ia pun menjadi berinisiatif untuk menitipkan karya ilmiah (tugas kampus) tersebut. Hal ini menjadi dasar kenapa plagiat diakatakan sebagai tradisi dalam dunia akademik karna anak plagiat akan terus lahir dari tahun ke tahun. Sebagaimana teori dari Ritzer and Goodman dalam Rachmatul Candra Ariani mengatakan bahwa secara sosiologis, plagiarisme sangat penting untuk dikaji karena plagiarisme berhubungan dengan masyarakat yang berada dalam lingkungan akademis dimana tindakan-tindakan mereka merupakan hasil dari interaksi-interaksi sosial dan proses sosial. Perspektif yang cocok untuk menjelaskan plagiarisme adalah perspektif perilaku sosial. Dimana sosiologi perilaku memusatkan perhatian pada hubungan antara pengaruh perilaku seorang aktor terhadap lingkungan dan dampak lingkungan terhadap perilaku aktor. Sehingga kunci utama dalam perspektif ini adalah aktor dan lingkungannya. ${ }^{22}$

Dari hasil wawancara tersebut dapat disimpulkan bahwa penyebab mahasiswa melakukan tindakan plagiat bervareasi mulai dari rasa malas, ketidak tauan dalam membuat karya ilmiah, keterbatasan alat dan bahan dalam membuat karya ilmiah, keterbatasan waktu dalam pembuatan karya ilmiah hingga alasan dikejar dead line .

\section{PENUTUP}

Berdasarkan uraian pada pembahasan sebelumnya, maka dapat ditegaskan bahwa proses plagiat yang dilakukan oleh mahasiswa

\footnotetext{
${ }^{21}$ Herqutanto, "Runtuhnya Tembok Kejujuran Akademik", eJKi, Vol 1, No 1, 1 April 2013, Diakses 27 Maret 2019, Jam 9:48.

${ }^{22}$ Rachmatul Candra Ariani, "Opini Mahasiswa Fakultas Ilmu Sosial Dan Ilmu Politik Universitas Airlangga Terhadap Plagiarisme”, Jurnal Social Dan Politik, Vol 18, No 2, 2016, 145
} 
perguruan tinggi di Bima dapat disebut gosh writer. Plagiarism model ini dilakukan dengan cara menitipkan judul tugas pada agen yang terpercaya mampu dalam membuat sebuah karya ilmiah dengan batasan waktu maksimal satu minggu untuk makalah, dan lebih daroi satu minggu untuk proposal dan skripsi. Bentuk plagiarisme yang mendominasi prilaku mahasiswa ialah plagiarisme serentak yaitu melakukan gunting tempel karya ilmiah milik orang lain seutuhnya dan dijadikan seolah karya ilmiah milik sendiri atau juga disebut dengan complete plagiarism. Selain bentuk itu, beberapa mahasiswa melakukan paraphrasing plagiat, yaitu plagiarisme berupa mengambil teks dari suatu sumber, kemudian dilakukan parafrase namun tidak disebut sumbernya, seakan teks tesebut asli miliknya. Adapun faktor penyebab plagiat pada penulisan karya ilmiah dikarenakan pemahaman mahasiswa yang kurang baik tentang plagiat dan pedoman serta tata cara penulisan termasuk pengutipan yang benar selain itu disebabkan pula oleh rasa malas, dikejar dead line, serta perasaan yang menganggap tugas berupa karya ilmiah yang diberikan ialah sebuah beban. Sehingga plagiat pada penulisan karya ilmiah mahasiswa di Bima dikategorikan sebagai plagiat sengaja.

\section{DAFTAR PUSTAKA}

Akh. Minhaji, Tradisi Akademik Di Perguruan Tinggi, Yogyakarta: Suka-Press, 2013.

Chairul Anwar, Hakikat Manusia Dalam Pendidikan, Yogyakarta, Suka-Press, 2014.

Faizuddin Harliansyah, "Plagiarisme dalam Karya Atau Publikasi Ilmiah dan Langkah Strategis Pencegahannya", Jurnal Libria, Vol. 9, No. 1, Juni 2017.

Febrina Nafisa Prihantini Dan Dian Indudewi, "Kesadaran Dan Perilaku Plagiarism Dikalangan Mahasiswa," Jurnal Dinamika Social Budaya, No. 1, Volume 18, 2016.

Herqutanto, "Runtuhnya Tembok Kejujuran Akademik", eJKi, Vol 1, No 1, 1 April 2013, Diakses 27 Maret 2019.

Https://Edukasi.Kompas.Com/Read/2010/04/20/10015667/Orang.Pintar.

Plagiat.Kompas, diakses Pada 3 Februari 2019.

Penjelasan Umum Undang-undang Nomor 20/2003sanksi bagi pelaku

plagiat, Lembaran Negara Republik Indonesia Tahun 2005 Nomor 112, Jakarta.

Putra R Marseb, Kiat Menghindari Plagiarism, Jakarta: Indeks, 2011. 
Rachmatul Candra Ariani, "Opini Mahasiswa Fakultas Ilmu Sosial Dan Ilmu Politik Universitas Airlangga Terhadap Plagiarisme”, Jurnal Social Dan Politik, Vol 18, No 2, 2016.

Rachmatul Candra Ariani, "Opini Mahasiswa Fakultas Ilmu Sosial Dan Ilmu Politik Universitas Airlangga Terhadap Plagiarisme”, Jurnal Social Dan Politik, Vol 18, No 2, 2016.

Seputar Indonesia 2012, di akses pada 2 maret 2019.

Siti Wachidah, " Plagiarisme Dalam Kata-Kata Mahasiswa: Analisis Teks Dengan Pendekatan Fungsional,"Jurnal Linguistik Indonesia, “ No. 2 ,Volume 18, 2013. 